\title{
Canadian contributions to the introduction and use of divinyl ether
}

\author{
Brendan T. Finucane, MB, BCh, BAO, FRCA, FRCPC
}

Published online: 4 June 2009

(C) Canadian Anesthesiologists' Society 2009

\section{Erratum to: Can J Anesth/J Can Anesth DOI 10.1007/BF03034057}

In the manuscript entitled: "Canadian contributions to the introduction and use of divinyl ether" published in the December 2008 issue, Can J Anesth 2008; 55: 853-8, the footnote on page 854 refers to a paper that was subsequently published. The actual citation is: Humble RM. The first use of divinyl ether as an anaesthetic agent in humans. In: Atkinson RS, Boulton TB (Eds). The History of Anaesthesia. Proceedings of the Second International Symposium. London: Royal Society of Medicine; 1989: 214-6. The publisher apologizes for this omission.

The online version of the original article can be found under doi: $10.1007 / \mathrm{BF} 03034057$.

B. T. Finucane, MB, BCh, BAO, FRCA, FRCPC ( $\square)$ Department of Anesthesiology and Pain Medicine, University of Alberta, Clinical Sciences Building 8-120, Edmonton, AB T6G 2G3, Canada

e-mail: bfinucan@ualberta.ca 